\title{
Identification of new Trichoderma strains with antagonistic activity against Botrytis cinerea
}

\author{
Aleksandra Bogumit, Lidia Sas Paszt*, Anna Lisek, \\ Pawet Trzciński, Anton Harbuzov
}

\author{
Department of Pomology \\ Research Institute of Horticulture, \\ Pomologiczna 18, 96-100 Skierniewice, Poland
}

\begin{abstract}
The antagonistic activity of 52 isolates of Trichoderma spp. against Botrytis cinerea was tested in in vitro conditions using the dual culture technique. The results revealed that all of the Trichoderma isolates had the ability to inhibit the mycelial growth of grey mould. The percentage reduction in the growth of Botrytis cinerea after six days of incubation at $25^{\circ} \mathrm{C}$ varied between $45-78 \%$. The isolates $\operatorname{Tr} 43$ and $\operatorname{Tr} 52$ showed the highest antagonistic activity $(\operatorname{Tr} 43-76 \% ; \operatorname{Tr} 52-78 \%)$. Biochemical and molecular identification indicated that both isolates were T.atroviride. The isolates showed differences in the utilisation of 11 to 96 different carbon sources. Additional biochemical tests revealed the ability of $\operatorname{Tr} 43$ and $\operatorname{Tr} 52$ to produce siderophores, indole-3-acetic acid and chitinases. Neither of the isolates gave positive results regarding phosphate solubilisation on Pikovskaya's medium.
\end{abstract}

Key words: antagonistic potential, grey mould, identification, Trichoderma spp.

\section{INTRODUCTION}

Grey mould caused by the fungus Botrytis cinerea Pers. ex Fr. is one of the most common crop diseases that is responsible for serious crop losses in more than 200 plant species worldwide (Williamson et al. 2007). This fungus can negatively affect all of the aboveground organs of plants, especially the buds, flowers and fruits (Elad et al. 2007). It normally enters through a wound or infects plants that are under stress, although it can also infect healthy plants, especially under humid conditions. There are a large number of fungicides with a high level of activity against grey mould (De Kock and Holz 1994, Markoglou and Ziogas 2002). Unfortunately, chemical protection negatively affects fruit and plant crops, the environment and human health. The use of fungicides may also lead to the occurrence of new resistant strains of plant pathogens. Recently, a worldwide tendency has been to use eco-friendly methods in plant protection (Hajieghrari et al. 2008). Biological control includes, for example, antagonistic microorganisms that naturally occur in the soil (Karkachi et al. 2010, Abano and Sam-Amoah 2012). Trichoderma is a group of filamentous fungi that are well known for their antagonism against several soil phytopathogens, involving fungi such as: Fusarium oxysporum, Rhizoctonia solani, Sclerotium rolfsii and Verticillium dahliae (Spiegel and Chet 1998, Jabnoun-Khiareddine et al. 2009). The antagonistic activity shown by Trichoderma species is connected with mycoparasitism, competition for nutrients

\footnotetext{
*Corresponding author.

Tel.: +48 4683452 35; fax: +48 4683332 28;

e-mail: lidia.sas@inhort.pl (L. Sas Paszt).
} 
and niche, production of antibiotics and enzymes (Howell 2003, Benitez et al. 2004, Verma et al. 2007). The antagonism of Trichoderma spp. has been observed both in in vitro conditions (Mishra et al. 2011) as well as in greenhouse and field trials (Kexiang et al. 2002). Some strains of Trichoderma also promote plant growth and yielding through enhanced production of plant hormones and vitamins, improved nutrient uptake and acquisition, etc. (Shanmugaiah et al. 2009, Joshi et al. 2010). Consequently, the antagonistic potential of Trichoderma spp. against pathogens is considered to be successfully used in biological control instead of the application of chemical plant protection products against phytopathogens.

The objectives of this study were to evaluate the antagonistic activity of Trichoderma isolates originating from Polish soils against Botrytis cinerea in in vitro conditions and to identify isolates with the highest capacity for pathogen inhibition.

\section{MATERIAL AND METHODS}

\section{Pure culture of Botrytis cinerea}

A pure culture of $B$. cinerea (isolate FFBC001) was isolated from the fruit of the 'Regent' grapevine cultivar and was stored for further use in the collection of microorganisms called SymbioBank, established in the Rhizosphere Laboratory of the Institute of Horticulture in Skierniewice (Poland).

\section{Pure cultures of Trichoderma spp.}

Fifty-two isolates of Trichoderma spp. were obtained from field soils and old orchard soils in central Poland (Tab. 1). Pure cultures were established with the use of soil-plate technique on Rose-Bengal Chloramphenicol Agar medium and incubated at $25^{\circ} \mathrm{C}$ for 5-7 days. The cultures were maintained in a deep freezer at $-80^{\circ} \mathrm{C}$ in Eppendorf tubes with $99.5 \%$ glycerol as a cryoprotectant. The Trichoderma isolates were identified to the genus level with the use of a morphological key (Watanabe 2010).

\section{Testing of the antagonistic activity of Trichoderma isolates}

In vitro tests were performed using the dual culture technique (Morton and Stroube 1955) on a PDA (potato dextrose agar) medium. Petri dishes with the medium were inoculated with discs six millimetres in diameter of the tested Trichoderma isolates and the $B$. cinerea isolate (six-day-old culture of each fungus). The discs of Trichoderma and Botrytis were placed on the opposite sides of each dish. The dishes were incubated at $26^{\circ} \mathrm{C}$ for six days. Three replicates (dishes) were used in each test and for each Trichoderma isolate. After six days of radial growth of $B$. cinerea colonies, the extent of the infection was measured and compared with the control (pure culture of $B$. cinerea). The reduction in the growth of $B$. cinerea colonies caused by the Trichoderma isolates was determined as follows (El-Naggar et al. 2008):

$$
\mathrm{R}=(\mathrm{A}-\mathrm{B}) / \mathrm{A} \times 100
$$

where: $\mathrm{R}$ - percentage reduction in the growth of pathogen, $\mathrm{A}$ - radius $(\mathrm{cm})$ of pathogen colony in control culture, $\mathrm{B}$ - radius $(\mathrm{cm})$ of pathogen colony in test dish.

The degree of antagonistic activity was estimated as follows (Sookchaoy et al. 2009): 4 - very high antagonistic activity $(\mathrm{R}>75), 3$ - high antagonistic activity $(\mathrm{R}=61-75), 2$ - moderate antagonistic activity $(\mathrm{R}=51-60), 1$ - low antagonistic activity $(\mathrm{R}<51)$.

Data were analysed using ANOVA. Tukey's multiple range test at $p=0.05$ was used for specific comparisons of the means. All calculations were done by means of the STATISTICA v.10 package (StatSoft, Inc. 2011).

\section{Identification of Trichoderma isolates}

The isolates of Trichoderma spp. that showed the best efficacy in inhibiting mycelial growth of $B$. cinerea were identified to the species level with the use of molecular and biochemical methods.

\section{Molecular identification of Trichoderma isolates}

Fungal genomic DNA of Trichoderma spp. was extracted using a commercial DNeasy Plant Mini Kit (Qiagen). PCR (polymerase chain reactions) were performed in a total volume of $20 \mu$, containing $1 \times$ reaction buffer, $0.2 \mathrm{mM}$ dNTPs, $0.2 \mu \mathrm{M}$ of each primer, $0.5 \mathrm{U}$ of Taq DNA polymerase (DreamTaq $^{\mathrm{TM}}$ Green, ThermoScientific) and $10 \mathrm{ng}$ of template DNA. PCR reactions were carried out in an S 1000 Thermal Cycler (BioRad) under the conditions involving an initial denaturation step at $95^{\circ} \mathrm{C}$ for 2 min., followed by 30 cycles of denaturation at $95^{\circ} \mathrm{C}$ for $30 \mathrm{~s}$, primer annealing at $55^{\circ} \mathrm{C}$ for $30 \mathrm{~s}$, extension at $72^{\circ} \mathrm{C}$ for $1 \mathrm{~min}$., and the final extension step at $72^{\circ} \mathrm{C}$ for 10 mins. ITS regions 1 and 2 and the 5.8S rDNA gene was amplified using the universal primers ITS4 (5'-TCC TCC GCT TAT TGA TAT GC-3') and ITS6 (5'-GAA GGT GAA GTC GTA ACA AGG-3') (White et al. 1990). The PCR products were sequenced using sequencing system 3730xl DNA Analyzer and BigDye ${ }^{\circledR T e r m i n a t o r}$ 
v.3.1 kit (Applied Biosystems). Related sequences were searched using the BLAST program from the NCBI (National Center for Biotechnology Information) database (http://www.ncbi.nlm.nih. gov/blast).

\section{Biochemical identification of Trichoderma isolates}

The biochemical characteristics of Trichoderma isolates were determined with the use of the Biolog Identification System (Biolog Inc., USA). Fresh cultures of Trichoderma spp. were streaked on a 2\% MEA (malt extract agar) medium and incubated at $26^{\circ} \mathrm{C}$ for seven days. The fungal suspension prepared in the IF-F inoculant's solution (quantification of $65 \%$ ) was inoculated into $\mathrm{FF}$ microplate and incubated at $26^{\circ} \mathrm{C}$ for seven days. The results were read off daily by inserting the microplate with a Trichoderma isolate into the Biolog's reader apparatus operated by the software of the Biolog Identification System (Microlog 3 v. 5.2.01). The fungi were identified down to the species level.

\section{Biochemical characterisation of Trichoderma isolates}

The Trichoderma isolates that showed the best antagonistic activity against $B$. cinerea on the Petri dishes were additionally tested to determine their ability to produce siderophores on the (CAS chrome azurol S) agar medium (Alexander and Zuberer 1991), indole-3-acetic acid (Gordon and Weber 1951), chitinase (Hsu and Lockwood 1975) and whether they were able to solubilise phosphate (Pikovskaya 1948).

\section{Preparation of the CAS agar medium}

The CAS agar medium was prepared from four solutions. The Fe-CAS indicator solution was prepared by mixing $10 \mathrm{ml}$ of $1 \mathrm{mM} \mathrm{FeCl} \cdot 6 \mathrm{H}_{2} \mathrm{O}$ (in $10 \mathrm{mM} / 1 \mathrm{HCl}$ ) with $50 \mathrm{ml}$ of an aqueous solution of CAS $(1.21 \mathrm{~g} / \mathrm{l})$ and adding it to $40 \mathrm{ml}$ of an aqueous solution of hexadecyltrimethylammonium bromide $(1.821 \mathrm{~g} / \mathrm{l})$. The buffer solution (solution 1) was prepared by dissolving $30.24 \mathrm{~g}$ of piperazine$\mathrm{N}, \mathrm{N}$-bis (2-ethanesulfonic acid) in $800 \mathrm{ml}$ of a salt solution (solution 2) containing $0.3 \mathrm{~g} \mathrm{~K}_{2} \mathrm{HPO}_{4}$, $0.5 \mathrm{~g} \mathrm{NaCl}_{1} 1.0 \mathrm{~g} \mathrm{NH}_{4} \mathrm{Cl}$. The $\mathrm{pH}$ was adjusted to 6.8 with $50 \% \mathrm{KOH}$. Before autoclaving $15 \mathrm{~g}$ of agar was added. Solution 3 contained (in $70 \mathrm{ml}$ water): $2 \mathrm{~g}$ glucose, $2 \mathrm{~g}$ mannitol, $493 \mathrm{mg} \mathrm{MgSO}_{4} \cdot 7 \mathrm{H}_{2} \mathrm{O}$, $11 \mathrm{mg} \mathrm{CaCl}, 1.17 \mathrm{mg} \mathrm{MnSO}_{4} \cdot \mathrm{H}_{2} \mathrm{O}, 1.4 \mathrm{mg} \mathrm{H}_{3} \mathrm{BO}_{3}$, $0.04 \mathrm{mg} \mathrm{CuSO} \cdot 5 \mathrm{H}_{2} \mathrm{O}, 1.2 \mathrm{mg} \mathrm{ZnSO} \cdot 7 \mathrm{H}_{2} \mathrm{O}$, $1.0 \mathrm{mg} \mathrm{NaMoO}{ }_{4} \cdot 2 \mathrm{H}_{2} \mathrm{O}$. Solution 4 contained $30 \mathrm{ml}$ of $10 \%$ casamino acids. All of the solutions were sterilised separately before mixing. Each of the Trichoderma isolates was inoculated into a Petri dish with CAS agar medium. A yellow halo surrounding the Trichoderma isolates indicated a positive reaction.

\section{Testing for indole-3-acetic acid production}

The production of indole-3-acetic acid was estimated using the Salkowski reagent $\left(1 \mathrm{ml} 0.5 \mathrm{~mol} / 1 \mathrm{FeCl}_{3}\right.$ and $49 \mathrm{ml} \mathrm{35 \%} \mathrm{HClO}_{4}$ ). The Trichoderma isolates were cultured in a sterilised Czapek broth $(30 \mathrm{~g}$ sucrose, $3 \mathrm{~g} \mathrm{NaNO}_{3}, 1 \mathrm{~g} \mathrm{~K}_{2} \mathrm{HPO}_{4}, 0.5 \mathrm{~g} \mathrm{KCl}, 0.5$ $\mathrm{g} \mathrm{MgSO}_{4} \cdot 7 \mathrm{H}_{2} \mathrm{O}, 0.01 \mathrm{~g} \mathrm{FeSO}_{4}, 1000 \mathrm{ml}$ distilled water) with L-tryptophan $(1 \mathrm{~g} / \mathrm{l})$ on a rotary shaker. After $96 \mathrm{~h}$ of incubation at room temperature, 500 $\mu \mathrm{l}$ of each Trichoderma culture was transferred to microtubes and centrifuged at $14,000 \mathrm{rpm}$ for two minutes. Afterwards $500 \mu \mathrm{l}$ of the Salkowski reagent was added. The microtubes were left for 30 minutes to allow colour development. A pink colour of the samples indicated the production of indole-3-acetic acid.

\section{Preparation of chitin agar medium}

The ability to produce chitinases was investigated using a chitin agar medium. Colloidal chitin was prepared by dissolving $15 \mathrm{~g}$ of powdered chitin in $200 \mathrm{ml}$ of concentrated $\mathrm{HCl}$. Chitin was dialysed by distilled water until the suspension adjusted a $\mathrm{pH}$ value of 5.5-6.0. Afterwards, $4 \mathrm{~g}$ of colloidal chitin was mixed with mineral salts: $0.7 \mathrm{~g} \mathrm{~K}_{2} \mathrm{HPO}_{4}$, $0.3 \mathrm{~g} \mathrm{KH}_{2} \mathrm{PO}_{4}, 0.5 \mathrm{~g} \mathrm{MgSO}_{4} \cdot 5 \mathrm{H}_{2} \mathrm{O}, 0.01 \mathrm{~g} \mathrm{FeSO}_{4}$ - $7 \mathrm{H}_{2} \mathrm{O}, 0.001 \mathrm{~g} \mathrm{ZnSO}_{4}, 0.001 \mathrm{~g} \mathrm{MnCl}_{2}, 20$ g agar and $1000 \mathrm{ml}$ distilled water. The agar medium was adjusted to $\mathrm{pH} 8.0$ with $50 \% \mathrm{KOH}$ and autoclaved. The Trichoderma isolates were inoculated onto the Petri dishes. The production of chitinases was observed as a discoloration of the agar medium.

\section{Preparation of Pikovskaya's agar medium}

The phosphate-solubilising ability was evaluated on Pikovskaya's agar medium consisting of $0.5 \mathrm{~g}$ yeast

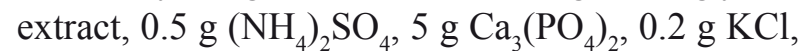
$0.1 \mathrm{~g} \mathrm{MgSO}_{4}, 0.0001 \mathrm{~g} \mathrm{MnSO}_{4}, 0.0001 \mathrm{~g} \mathrm{FeSO}_{4}$, $10 \mathrm{~g}$ glucose, $15 \mathrm{~g}$ agar and $1000 \mathrm{ml}$ distilled water. Each of the Trichoderma isolates was inoculated onto a Petri dish with Pikovskaya's agar medium. A clear dissolution zone around the isolates indicated a positive reaction.

\section{RESULTS}

In the present study, 52 isolates of Trichoderma were screened for antagonistic activity against 
Table 1. Inhibition of the growth of Botrytis cinerea by 52 Trichoderma isolates and their antagonistic activity against this pathogen in dual culture tests

\begin{tabular}{|c|c|c|c|c|c|c|c|c|c|}
\hline $\begin{array}{l}\text { Trichoderma } \\
\text { isolates }\end{array}$ & $\begin{array}{l}\text { Location of } \\
\text { sampling }\end{array}$ & $\begin{array}{l}\text { Species } \\
\text { of fruit } \\
\text { trees }\end{array}$ & $\begin{array}{l}\text { Average de- } \\
\text { gree of growth } \\
\text { inhibition after } \\
6 \text { days of incu- } \\
\text { bation (\%) }\end{array}$ & $\begin{array}{l}\text { Antagonistic } \\
\text { activity } \\
\text { (on 1-4 } \\
\text { scale*) }\end{array}$ & $\begin{array}{l}\text { Trichoderma } \\
\text { isolates }\end{array}$ & $\begin{array}{l}\text { Location of } \\
\text { sampling }\end{array}$ & $\begin{array}{l}\text { Species } \\
\text { of fruit } \\
\text { trees }\end{array}$ & $\begin{array}{l}\text { Average degree } \\
\text { of growth inhibi- } \\
\text { tion after } \\
6 \text { days of incuba- } \\
\text { tion }(\%)\end{array}$ & $\begin{array}{l}\text { Antagonistic } \\
\text { activity } \\
\text { (on 1-4 } \\
\text { scale*) }\end{array}$ \\
\hline $\operatorname{Tr} 3$ & Willanów & cherry & $63 \mathrm{c}-\mathrm{j} * *$ & 3 & $\operatorname{Tr} 29$ & $\begin{array}{c}\text { Dębowa } \\
\text { Góra }\end{array}$ & cherry & $62 c-j$ & 3 \\
\hline $\operatorname{Tr} 4$ & Willanów & cherry & $58 \mathrm{f}-\mathrm{j}$ & 2 & $\operatorname{Tr} 30$ & Stryczowice & pear & $67 \mathrm{~b}-\mathrm{g}$ & 3 \\
\hline $\operatorname{Tr} 5$ & Willanów & cherry & $67 \mathrm{~b}-\mathrm{h}$ & 3 & $\operatorname{Tr} 31$ & Stryczowice & pear & $68 \mathrm{~b}-\mathrm{g}$ & 3 \\
\hline Tr6 & Nowy Dwór & cherry & $64 c-j$ & 3 & $\operatorname{Tr} 32$ & Stryczowice & pear & $67 \mathrm{~b}-\mathrm{g}$ & 3 \\
\hline $\operatorname{Tr} 7$ & Nowy Dwór & cherry & $63 c-j$ & 3 & $\operatorname{Tr} 33$ & Stryczowice & pear & $66 \mathrm{~b}-\mathrm{i}$ & 3 \\
\hline $\operatorname{Tr} 8$ & Nowy Dwór & cherry & $62 c-j$ & 3 & $\operatorname{Tr} 34$ & Stryczowice & pear & $67 \mathrm{~b}-\mathrm{g}$ & 3 \\
\hline Tr9 & $\begin{array}{l}\text { Nowe Ber- } \\
\text { ezowo }\end{array}$ & apple & $65 \mathrm{c}-\mathrm{i}$ & 3 & $\operatorname{Tr} 35$ & Stryczowice & pear & $64 c-j$ & 3 \\
\hline $\operatorname{Tr} 10$ & $\begin{array}{l}\text { Nowe Ber- } \\
\text { ezowo }\end{array}$ & apple & $54 \mathrm{jk}$ & 2 & $\operatorname{Tr} 36$ & Stryczowice & pear & $72 \mathrm{a}-\mathrm{c}$ & 3 \\
\hline $\operatorname{Tr} 11$ & $\begin{array}{c}\text { Nowe Ber- } \\
\text { ezowo }\end{array}$ & apple & $64 c-j$ & 3 & $\operatorname{Tr} 37$ & Stryczowice & plum & 68 b-g & 3 \\
\hline $\operatorname{Tr} 12$ & $\begin{array}{l}\text { Nowe Ber- } \\
\text { ezowo }\end{array}$ & apple & $65 \mathrm{~b}-\mathrm{i}$ & 3 & $\operatorname{Tr} 38$ & Stryczowice & plum & $71 \mathrm{a}-\mathrm{d}$ & 3 \\
\hline $\operatorname{Tr} 13$ & $\begin{array}{l}\text { Nowe Ber- } \\
\text { ezowo }\end{array}$ & apple & $58 \mathrm{f}-\mathrm{j}$ & 2 & $\operatorname{Tr} 39$ & Stryczowice & plum & 70 a-e & 3 \\
\hline $\operatorname{Tr} 14$ & $\begin{array}{c}\text { Nowe Ber- } \\
\text { ezowo }\end{array}$ & apple & $55 \mathrm{ij}$ & 2 & $\operatorname{Tr} 40$ & Stryczowice & plum & 70 a-e & 3 \\
\hline $\operatorname{Tr} 15$ & $\begin{array}{l}\text { Nowe Ber- } \\
\text { ezowo }\end{array}$ & apple & $56 \mathrm{ij}$ & 2 & $\operatorname{Tr} 41$ & Stryczowice & plum & $56 \mathrm{ij}$ & 2 \\
\hline $\operatorname{Tr} 16$ & $\begin{array}{l}\text { Nowe Ber- } \\
\text { ezowo }\end{array}$ & apple & 60 e-j & 3 & $\operatorname{Tr} 42$ & Stryczowice & plum & $64 c-j$ & 3 \\
\hline $\operatorname{Tr} 17$ & $\begin{array}{l}\text { Nowe Ber- } \\
\text { ezowo }\end{array}$ & apple & $56 \mathrm{ij}$ & 2 & $\operatorname{Tr} 43$ & Przeworsk & apple & $76 \mathrm{ab}$ & 4 \\
\hline $\operatorname{Tr} 18$ & $\begin{array}{l}\text { Nowe Ber- } \\
\text { ezowo }\end{array}$ & apple & $61 \mathrm{~d}-\mathrm{j}$ & 3 & $\operatorname{Tr} 44$ & Przeworsk & apple & $61 \mathrm{~d}-\mathrm{j}$ & 3 \\
\hline $\operatorname{Tr} 19$ & $\begin{array}{l}\text { Nowe Ber- } \\
\text { ezowo }\end{array}$ & apple & $61 \mathrm{~d}-\mathrm{j}$ & 3 & $\operatorname{Tr} 45$ & Przeworsk & apple & 58 g-j & 2 \\
\hline $\operatorname{Tr} 20$ & $\begin{array}{l}\text { Nowe Ber- } \\
\text { ezowo }\end{array}$ & apple & $59 \mathrm{f}-\mathrm{j}$ & 2 & $\operatorname{Tr} 46$ & Przeworsk & apple & $61 \mathrm{~d}-\mathrm{j}$ & 3 \\
\hline $\operatorname{Tr} 21$ & $\begin{array}{c}\text { Dębowa } \\
\text { Góra }\end{array}$ & cherry & $60 e-j$ & 3 & $\operatorname{Tr} 47$ & Przeworsk & apple & $61 \mathrm{~d}-\mathrm{j}$ & 3 \\
\hline $\operatorname{Tr} 22$ & $\begin{array}{c}\text { Dębowa } \\
\text { Góra }\end{array}$ & cherry & $63 c-j$ & 3 & $\operatorname{Tr} 48$ & Przeworsk & apple & $58 \mathrm{f}-\mathrm{j}$ & 2 \\
\hline $\operatorname{Tr} 23$ & $\begin{array}{c}\text { Dębowa } \\
\text { Góra }\end{array}$ & cherry & $57 \mathrm{~h}-\mathrm{j}$ & 2 & $\operatorname{Tr} 49$ & Przeworsk & apple & 67 b-g & 3 \\
\hline $\operatorname{Tr} 24$ & $\begin{array}{c}\text { Dębowa } \\
\text { Góra }\end{array}$ & cherry & $67 \mathrm{~b}-\mathrm{h}$ & 3 & $\operatorname{Tr} 50$ & Przeworsk & apple & $56 \mathrm{~h}-\mathrm{j}$ & 2 \\
\hline $\operatorname{Tr} 25$ & $\begin{array}{c}\text { Dębowa } \\
\text { Góra }\end{array}$ & cherry & $65 c-i$ & 3 & $\operatorname{Tr} 51$ & Przeworsk & apple & $62 c-j$ & 3 \\
\hline $\operatorname{Tr} 26$ & $\begin{array}{l}\text { Dębowa } \\
\text { Góra }\end{array}$ & cherry & $63 c-j$ & 3 & $\operatorname{Tr} 52$ & Przeworsk & apple & $78 \mathrm{a}$ & 4 \\
\hline $\operatorname{Tr} 27$ & $\begin{array}{l}\text { Dębowa } \\
\text { Góra }\end{array}$ & cherry & $59 \mathrm{f}-\mathrm{j}$ & 2 & $\operatorname{Tr} 53$ & Przeworsk & apple & $45 \mathrm{k}$ & 1 \\
\hline $\operatorname{Tr} 28$ & $\begin{array}{l}\text { Dębowa } \\
\text { Góra }\end{array}$ & cherry & $61 \mathrm{~d}-\mathrm{j}$ & 3 & $\operatorname{Tr} 54$ & Przeworsk & apple & $68 b-f$ & 3 \\
\hline
\end{tabular}

$* 1=$ low antagonistic activity $(\mathrm{R}<51), 2=$ moderate antagonistic activity $(\mathrm{R}=51-60), 3=$ high antagonistic activity $(\mathrm{R}=61-75)$, $4=$ very high antagonistic activity $(\mathrm{R}>75)$

**Values marked with the same letter do not differ significantly at $\mathrm{p}=0.05$ 
B. cinerea. All of the tested isolates restricted the growth area and intensity of grey mould colonies (Tab. 1). The average level of this growth inhibition varied between $45-78 \%$. Over $60 \%$ of the isolates showed a high level of antagonistic activity, ranging from $61 \%$ to $75 \%$. Among the tested Trichoderma isolates, six isolates showed the best efficacy in inhibiting mycelial growth of $B$. cinerea at a level of $70 \%$ for $\operatorname{Tr} 39$ and $\operatorname{Tr} 40,71 \%$ for $\operatorname{Tr} 38,72 \%$ for $\operatorname{Tr} 36,76 \%$ for $\operatorname{Tr} 43$ and $78 \%$ for $\operatorname{Tr} 52$. In comparison with the other Trichoderma isolates, the differences were statistically significant. However, according to the scale used by Sookchaoy et al. (2009), very high antagonistic activity (4 points on a 1-4 scale) was shown by two strains: $\operatorname{Tr} 43$ and Tr52 (Fig. 1).

\section{Results of Trichoderma identification}

A comparison of sequences (the sequence of 601 nucleotides for the isolate $\operatorname{Tr} 43$ and the sequence of 600 nucleotides for the isolate Tr52) with the NCBI sequences database allowed the identification of both isolates as the Trichoderma atroviride P. Karst. The identities of the results were as follows: $99 \%$ for isolate $\operatorname{Tr} 43$ and $100 \%$ for isolate $\operatorname{Tr} 52$.

Table 2. Results for the utilisation of different carbon sources after $72 \mathrm{~h}$ of incubation at $26^{\circ} \mathrm{C}$ obtained with the Biolog Identification System

\begin{tabular}{|c|c|c|c|c|c|c|c|c|}
\hline \multirow{3}{*}{$\begin{array}{l}\text { Utilisation of different carbon } \\
\text { sources }\end{array}$} & \multirow{2}{*}{\multicolumn{2}{|c|}{$\frac{\text { Isolate }}{\operatorname{Tr} 43 \operatorname{Tr} 52}$}} & \multirow{3}{*}{$\begin{array}{c}\begin{array}{l}\text { Utilisation of different carbon } \\
\text { sources }\end{array} \\
\text { D-Ribose }\end{array}$} & \multirow{2}{*}{\multicolumn{2}{|c|}{$\frac{\text { Isolate }}{\operatorname{Tr} 43 \operatorname{Tr} 52}$}} & \multirow{3}{*}{$\begin{array}{c}\begin{array}{c}\text { Utilisation of different carbon } \\
\text { sources }\end{array} \\
\text { Lactulose }\end{array}$} & \multirow{2}{*}{\multicolumn{2}{|c|}{$\frac{\text { Isolate }}{\operatorname{Tr} 43 \operatorname{Tr} 52}$}} \\
\hline & & & & & & & & \\
\hline & - & - & & + & + & & - & - \\
\hline Tween 80 & + & + & Salicin & + & + & Maltitol & - & - \\
\hline N-Acetyl-D-Galactosamine & - & - & Sedoheptulosan & - & - & Maltose & + & - \\
\hline N-Acetyl-D-Glucosamine & + & + & D-Sorbitol & + & + & Maltotriose & + & + \\
\hline N-Acetyl-D-Mannosamine & - & - & L-Sorbose & + & + & D-Mannitol & + & + \\
\hline Adonitol & - & - & Stachyose & + & + & D-Mannose & + & + \\
\hline Amygdalin & + & + & Sucrose & + & + & D-Melezitose & - & - \\
\hline D-Arabinose & - & + & D-Tagatose & + & - & D-Melibiose & + & + \\
\hline L-Arabinose & + & + & D-Trehalose & + & + & $\alpha$-Methyl-D-Galactoside & + & + \\
\hline D-Arabitol & + & + & Turanose & + & + & $\beta$-Methyl-D-Galactoside & - & - \\
\hline Arbutin & + & + & Xylitol & + & + & $\alpha$-Methyl-D-Glucoside & - & - \\
\hline D-Cellobiose & + & + & D-Xylose & + & + & $\beta$-Methyl-D-Glucoside & + & + \\
\hline$\alpha$-Cyclodextrin & - & - & $\gamma$-Amino-butyric Acid & + & + & Palatinose & - & - \\
\hline$\beta$-Cyclodextrin & - & - & Bromosuccinic Acid & + & + & D-Psicose & - & - \\
\hline Dextrin & + & + & Fumaric Acid & - & + & D-Raffinose & + & + \\
\hline i-Erythritol & + & + & $\beta$-Hydroxy-butyric Acid & + & + & L-Rhamnose & - & - \\
\hline D-Fructose & + & + & $\gamma$-Hydroxy-butyric Acid & + & + & L-Alanyl-Glycine & + & + \\
\hline L-Fucose & - & - & p-Hydroxyphenyl-acetic Acid & - & - & L-Asparagine & + & + \\
\hline D-Galactose & + & + & $\alpha$-Keto-glutaric Acid & - & + & L-Aspartic Acid & + & + \\
\hline D-Galacturonic Acid & - & - & D-Lactic Acid Methyl Ester & - & + & L-Glutamic Acid & + & + \\
\hline Gentiobiose & + & + & L-Lactic Acid & - & + & Glycyl-L-Glutamic Acid & - & + \\
\hline D-Gluconic Acid & - & - & D-Malic Acid & + & + & L-Ornithine & + & + \\
\hline D-Glucosamine & - & - & L-Malic Acid & - & - & L-Phenylalanine & + & + \\
\hline$\alpha$-D-Glucose & + & + & Quinic Acid & + & + & L-Proline & + & + \\
\hline Glucose-1-Phosphate & + & + & D-Saccharic Acid & - & + & L-Pyroglutamic Acid & + & + \\
\hline Glucuronamide & - & - & Sebacic Acid & - & - & L-Serine & + & + \\
\hline D-Glucuronic Acid & + & + & Succinamic Acid & - & - & L-Threonine & + & + \\
\hline Glycerol & + & + & Succinic Acid & - & + & 2-Amino Ethanol & + & + \\
\hline Glycogen & + & + & Succinic Acid Mono-Methyl Ester & - & - & Putrescine & - & + \\
\hline m-Inositol & - & - & N-Acetyl-L-Glutamic Acid & - & - & Adenosine & + & + \\
\hline 2-Keto-D-Gluconic Acid & + & + & Alaninamide & + & + & Uridine & - & + \\
\hline$\alpha$-D-Lactose & - & + & L-Alanine & + & + & Adenosine-5'-Monophosphate & - & + \\
\hline
\end{tabular}




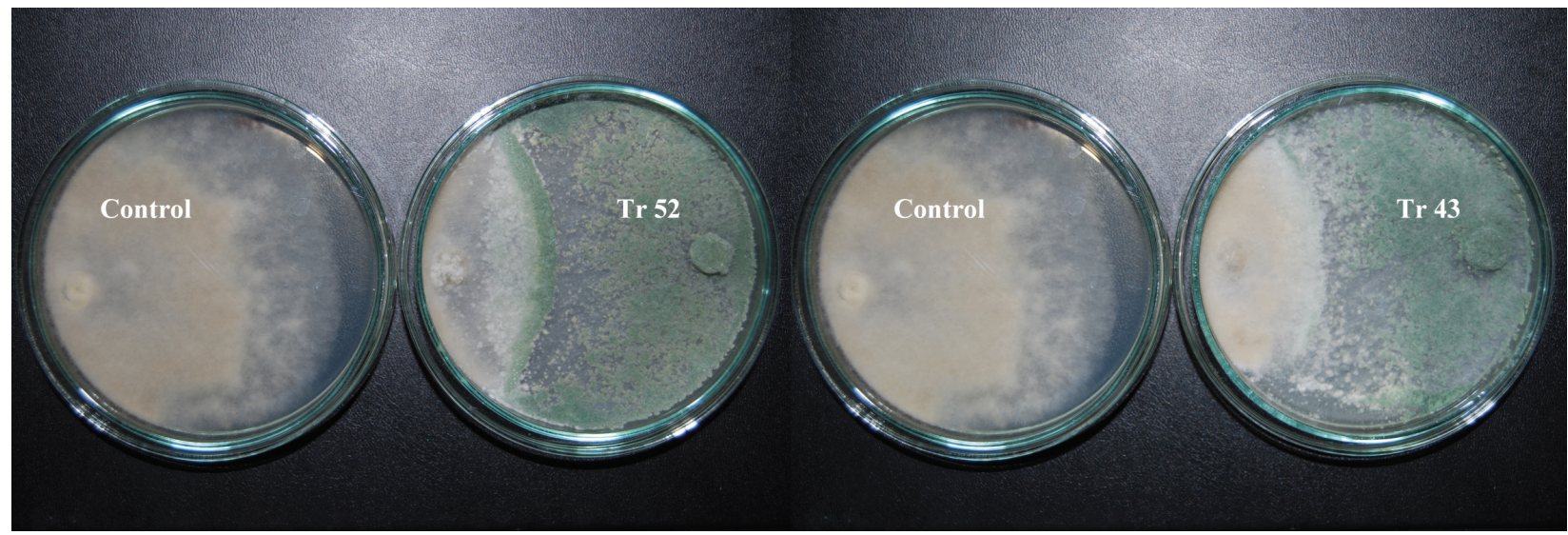

Figure 1. Antagonistic activity of isolates $\operatorname{Tr} 43$ and Tr52 against Botrytis cinerea (on the left: pure culture of B. cinerea, on the right: the dual culture of B. cinerea and Trichoderma isolate)

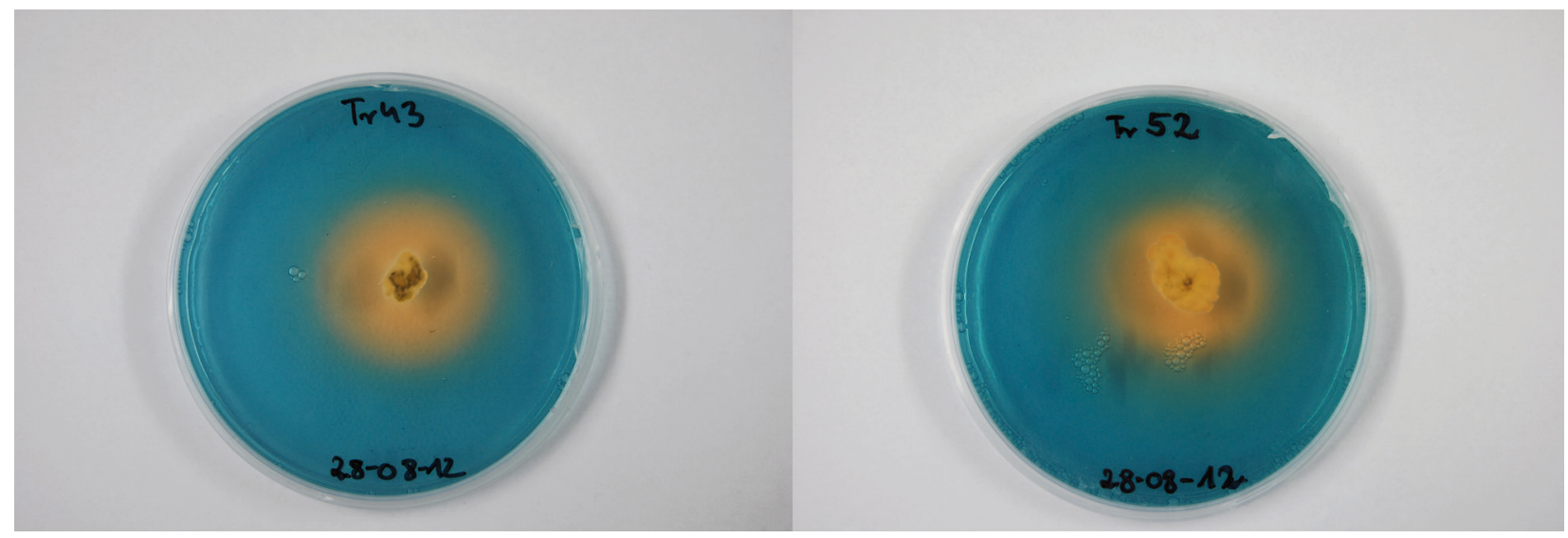

Figure 2. Siderophore production by isolates $\operatorname{Tr} 43$ and $\operatorname{Tr} 52$ on CAS agar medium

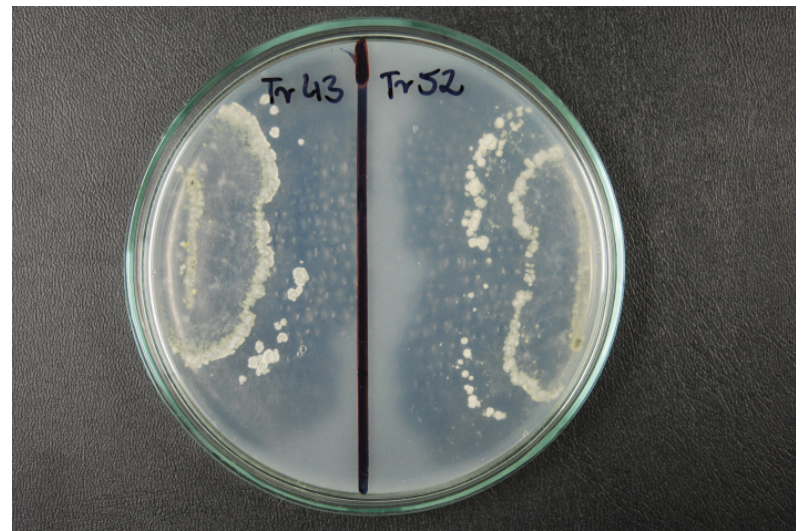

Figure 3. Visualisation of chitynolytic activity by Trichoderma isolates Tr43 and Tr52. The clear zone around the isolates indicates chitinase production

Biochemical identification using the Biolog Identification System was performed during seven days of incubation at $26^{\circ} \mathrm{C}$. Using this method, isolate $\operatorname{Tr} 52$ was identified after $96 \mathrm{~h}$ as $T$. atroviride. The probability of correct identification was $94 \%$ and the similarity to standard T. atroviride was 0.604. Isolate $\operatorname{Tr} 43$ was not positively identified, but the results indicate that it is the most similar to $T$. atroviride (similarity was 0.512 ). The isolates $\operatorname{Tr} 43$ and $\operatorname{Tr} 52$ showed differences in the utilisation of 11 to 96 different carbon sources. In contrast to Tr52, Trichoderma Tr43 utilised maltose and D-tagatose, whereas isolate $\operatorname{Tr} 52$ utilised in wells D-arabinose, $\alpha$-D-lactose, fumaric acid, $\alpha$-ketoglutaric acid, D-lactic acid methyl ester, L-lactic acid, D-saccharic acid, succinic acid and glycyl-Lglutaric acid (Tab. 2).

\section{Results of additional biochemical tests on Tr43 and Tr52 Trichoderma isolates}

Both of the Trichoderma isolates produced siderophores, which was visualised on the CAS agar medium as an orange halo developed around the isolates (Fig. 2). The halo was caused by siderophores chelating $\mathrm{Fe}$ from the Fe-CAS dye complex. Production of indole-3-acetic acid from L-tryptophan was observed as a change in the colour of the medium from colourless to a pink colour (addition of the Salkowski reagent). Chitynolytic activity was also exhibited by both Trichoderma 
Table 3. Results of additional tests for the biochemical characterisation of Trichoderma isolates $\operatorname{Tr} 43$ and $\operatorname{Tr} 52$

\begin{tabular}{lcccc}
\hline $\begin{array}{l}\text { Trichoderma } \\
\text { isolates }\end{array}$ & $\begin{array}{c}\text { Siderophores produc- } \\
\text { tion }\end{array}$ & $\begin{array}{c}\text { Indole-3-acetic acid } \\
\text { production }\end{array}$ & $\begin{array}{c}\text { Phosphate solubilisa- } \\
\text { tion }\end{array}$ & $\begin{array}{c}\text { Chitynolytic } \\
\text { activity }\end{array}$ \\
\hline Tr43 & + & + & - & + \\
$\operatorname{Tr} 52$ & + & + & - & + \\
\hline
\end{tabular}

isolates, which was observed as a discoloration of the agar medium (Fig. 3). Neither of the isolates gave positive results regarding phosphate solubilisation on Pikovskaya's medium since the clear zone did not appear nor was visible in this medium (Tab. 3).

\section{DISCUSSION}

Trichoderma spp. are widespread in the soil as saprophytic fungi highly competitive to plant pathogens. Among Trichoderma isolates, the most studied are T. harzianum (Chaur-Tsuen and Chien-Yih 2002), T. reesei (El-Naggar et al. 2008), T. atroviride (Brunner et al. 2005) and T. viride (Mishra et al. 2011). The biological control activity of the Trichoderma strains against fungal phytopathogens has been tested and described in several research papers (Meszka and Bielenin 2009, Joshi et al. 2010, Lone et al. 2012). Trichoderma isolates have been shown to be successful in controlling soilborne diseases in the greenhouse and under field conditions. Some of the Trichoderma strains are currently available as components of commercial bioproducts: KRL-AG2 (T. harzianum) controls a wide range of soil-borne diseases (Spiegel and Chet 1998), Trichodex (T. harzianum) is used against B. cinerea, Sclerotinia sclerotiorum, Cladosporium fulvum diseases in greenhousegrown tomato and cucumber, and in vineyards (Freeman et al. 2004), Binab T (T. harzianum and T. polysporum) controls wound decay and wood rot (Mehrotra and Aggarwal 2003), Supresivit (T. harzianum) inhibits the growth of Phytophthora spp. and Pythium ultimum and might stimulate the growth of plants (Brožová 2004).

In this study, the results of the dual culture tests revealed antagonistic activity of all 52 Trichoderma isolates against $B$. cinerea. The Trichoderma isolates grew rapidly and intensively covered the entire surface of the Petri dishes after 10 days. The most effective strains revealed more than $70 \%$ of the growth inhibition of $B$. cinerea. An isolate of T. reesei studied by El-Naggar et al. (2008) showed only a $30 \%$ reduction in the growth of $B$. cinerea, $40.2 \%$ in the growth of $B$. fabae and only $4 \%$ in the growth of $B$. allii after five days of incubation.
Fiume and Fiume (2006) observed the antagonistic activity of $T$. harzianum against grey mould at a range from $4.7 \%$ after three days of incubation and up to $75.76 \%$ after seven days of incubation. They also reported no inhibition halo between $B$. cinerea and T. harzianum colonies, which suggests that the antagonistic effect of T. harzianum isolates is based on the competition for niche and nutrients and not on a chemical aggressiveness or classic antibiosis. In the present study all the Trichoderma isolates achieved an average percentage of growth reduction above $45 \%$ after six days. A clear zone between all of the Trichoderma isolates and $B$. cinerea was also not observed. However, additional biochemical tests revealed the ability of the isolates $\operatorname{Tr} 43$ and $\operatorname{Tr} 52$ identified as T. atroviride to produce the chitinases. An isolate of T. atroviride studied by Matroudi et al. (2009) showed chitinase and $\beta-1.3$ glucanase activity. Both of these extracellular enzymes are connected with mycoparasitism that is initiated against phytopathogenic fungi. Chitinases are able to lyse the hard chitin cell wall of mature hyphae, conidia, chlamydospores and sclerotia (Harighi et al. 2007).

T. atroviride is well-known as a biological control agent for a wide range of economically important aerial and soil-borne plant pathogens (Brunner et al. 2005). McLean et al. (2012) observed antagonistic activity of $T$. atroviride against Sclerotium cepivorum, whereas Anita and Ponmurugan (2011) reported that $T$. atroviride were highly effective in controlling Phomopsis canker diseases in tea plants. The tests performed by Matroudi et al. (2009) also revealed the high antagonistic activity of T. atroviride. That isolate produced $85 \%$ inhibition in the growth of $S$. sclerotiorum after three days and $93 \%$ after four days of incubation. The dual culture tests against other fungal phytopathogens (for example Verticillium dahlia or Fusarium oxysporum) are essential to perform. The published literature data clearly indicate that the antagonistic activity of Trichoderma species is based on mycoparasitism, the production of antibiotics and enzymes, and is usually directed against the development of a few pathogens. Hajieghrari et al. (2008) observed an inhibitory effect of 
Trichoderma isolates on the growth of Rhizoctonia solani, Macrophomina phaseoli, Phytophthora cactorum and Fusarium graminearum. In a study by Joshi et al. (2010), the antagonistic activity of Trichoderma was shown against Sclerotium rolfsii, $R$. solani and S. sclerotiorum, whereas Siameto et al. (2010) described antifungal properties of $T$. harzianum against $F$. oxysporum f. sp lycopersici, $F$. oxysporum f. sp phaseoli and $F$. graminearum.

Additional biochemical tests for siderophore production and indole-3-acetic acid production suggest that the isolates $\operatorname{Tr} 43$ and $\operatorname{Tr} 52$ might also stimulate plant growth. Indole-3-acetic acid is an auxin that stimulates plant growth and development. Siderophores reduce $\mathrm{Fe}^{3+}$ ions to $\mathrm{Fe}^{2+}$ ions that can be taken up by plants and efficiently transported from the roots to the shoots. Iron is an important microelement that participates in a variety of redox reactions associated with many important metabolic processes, such as respiration, photosynthesis and the metabolism of nitrogen compounds. Microorganisms that produce siderophores competitively inhibit the growth of plant pathogens with a less efficient iron uptake system. Hoyos-Carvajal et al. (2009) evaluated the production of potential growth-promoting metabolites by 101 isolates of Trichoderma. More than $50 \%$ of the assessed strains showed an ability to produce siderophores on a CAS agar medium. The production of indole-3-acetic acid was observed in $60 \%$ of the isolates. Some of the Trichoderma strains that revealed plant growth promotion mechanisms in laboratory tests also showed an ability to enhance the growth of bean seedlings in the early stages of development. Both of the Trichoderma isolates gave negative results on Pikovskaya's medium. Microorganisms dissolve phosphates by producing inorganic and organic acids. The tricalcium phosphate solubilsing ability depends on various factors like carbon sources, salinity, $\mathrm{pH}$ of medium, etc. Yadav et al. (2011) observed the maximum significant tricalcium phosphate solubilisation of Aspergillus niger strain at $1 \% \mathrm{CaCl}_{2}$ in saline conditions and with glucose used as a carbon source. Mahamuni et al. (2012) used dextrose and $1 \% \mathrm{NaCl}$ to isolate phosphate solubilising fungi from the rhizosphere soil of sugarcane and sugar beet. In our studies, we used Pikovskaya's medium containing $1 \% \mathrm{KCl}$ and glucose as a carbon source to estimate the phosphate solubilising activity. According to the literature, this standard medium is considered to be a good selective medium for the isolation of phosphate solubilising microorganisms.

\section{CONCLUSIONS}

1. In in vitro conditions, Trichoderma isolates $\operatorname{Tr} 43$ and $\operatorname{Tr} 52$ exhibited the highest antagonistic activity against $B$. cinerea.

2. Additional biochemical tests (siderophore production, indole-3-acetic acid production) revealed the production of potential growth promoting metabolites by isolates $\operatorname{Tr} 43$ and $\operatorname{Tr} 52$.

\section{ACKNOWLEDGEMENTS}

This study was supported by a grant from the EU Regional Development Fund through the Polish Innovation Economy Operational Programme, contract No. UDA-POIG.01.03.01-10-109/08-00.

\section{REFERENCES}

Aвano E.E., SAm-Амодн L.K., 2012. Application of antagonistic microorganisms for the control of postharvest decays in fruits and vegetables. Int. J. Adv. Biol. Res. 2(1): 1-8.

Alexander D.B., Zuberer D.A., 1991. Use of chrome azurol $\mathrm{S}$ reagents to evaluate siderophore production by rhizosphere bacteria. Biol. Fertil. Soils 12: 39-45.

Anita S., Ponmurugan P., 2011. In vitro evaluation of Trichoderma atroviride against Phomopsis theae a casual agent of collar canker disease in tea plants. Int. J. Agric. Res. 6(8): 620-631.

Benitez T., Rincón A.M., Limón M.C., Codón A.C., 2004. Biocontrol mechanisms of Trichoderma strains. Int. Microbiol. 7: 249-260.

BrožovÁ J., 2004. Mycoparasitic fungi Trichoderma spp. in plant protection - Review. Plant Protect. Sci. 40: $63-74$

Brunner K., Zeilinger S., Ciliento R., Woo S.L., Lorito M., KuBiceK C.P., MACH R.L., 2005. Improvement of the fungal biocontrol agent Trichoderma atroviride to enhance both antagonism and induction of plant systemic resistance. Appl. Environ. Microbiol. 71: 3959-3965.

Chaur-Tsuen L., Chien-YiH L., 2002. Screening strains of Trichoderma spp. for plant growth enhancement in Taiwan. Plant Pathol. Bul. 11: 215-220.

De Kock P.J., Holz G., 1994. Application of fungicides against postharvest Botrytis cinerea bunch rot of table grapes in the Western Cape. S. Afr. J. Enol. Vitic. 15: 33-40.

Elad Y., Williamson B., Tudzynski P., Delen N., 2007. Botrytis: Biology, Pathology and Control. Springer, The Netherlands.

El-Naggar M., Kövics G.J., SÁndor E, Irinyi L., 2008. Mycoparasitism and antagonistic efficiency of Trichoderma reesei against Botrytis spp. Contrib. Bot. 43: 141-147. 
Fiume F., Fiume G., 2006. Biological control of Botrytis gray mould on tomato cultivated in greenhouse. Commun Agric. Appl. Biol. Sci. 71(3 Pt B): 897-908.

Freeman S., Minz D., Kolesnik I., Barbul O., Zveibil A., Mayman M., 2004. Trichoderma biocontrol of Colletotrichum acutatum and Botrytis cinerea and survival in strawberry. Eur. J. Plant Path. 110: 361-370.

Gordon S., Weber R.P., 1951. The colorimetric estimation of IAA. Plant Physiol. 26: 192-195.

Hajieghrari B., Torabi-Giglou M., Mohammadi M.R., DAVARI M., 2008. Biological potential of some Iranian Trichoderma isolates in the control of soil borne plant pathogenic fungi. Afr. J. Biotechnol. 7: 967-972.

Harighi M.J., Zamani M.R., Motallebi M., 2007. Evaluation of antifungal activity of purified chitinase 42 from Trichoderma atroviride PTCC5220. Biotechnol. 6(1): 28-33.

Howell C.R., 2003. Mechanisms employed by Trichoderma species in the biological control of plant diseases: the history and evolution of current concepts. Plant Dis. 87: 4-10.

Hoyos-Carvajal L., Orduz S., Bissett J., 2009. Growth stimulation in bean (Phaseolus vulgaris L.) by Trichoderma. Biol. Control 51: 409-416.

Hsu S.C., Lockwood J.L., 1975. Powdered chitin agar as a selective medium for enumeration of Actinomycetes in water and soil. Appl. Microbiol. 29: 422-426.

Jabnoun-Khiareddine H., Daami-Remadi M., Ayed F., El Mahjoub M., 2009. Biological control of tomato Verticillium wilt by using indigenous Trichoderma spp. Afr. J. Plant Sci. Biotech. 3 (Special Issue 1): 26-36.

Joshi B.B., Bhatt R.P., Bahukhandi D., 2010.Antagonistic and plant growth activity of Trichoderma isolates of Western Himalayas. J. Environ. Biol. 31: 921-928.

Karkachi N.E., Gharbi S., Kihal M., Henni J.E., 2010. Biological control of Fusarium oxysporum f.sp. lycopersici isolated from algerian tomato by Pseudomonas fluorescens, Bacillus cereus, Serratia marcescens and Trichoderma harzianum. Res. J. Agron. 4: 31-34.

Kexiang G., Xiaoguang L., Yonghong L., Tianbo Z., Shuliang W., 2002. Potential of Trichoderma harzianum and T. atroviride to control Botryosphaeria berengeriana $\mathrm{f}$. sp. piricola, the cause of apple ring rot. J. Phytopathol. 150: 271-276.

Lone M.A., Wani M.R., Sheikh S.A., Sahay S., Dar M.S., 2012. Antagonistic potentiality of Trichoderma harzianum against Cladosporium spherospermum, Aspergillus niger and Fusarium oxysporum. J. Biol. Agric. Health. 2: 72-76.

Mahamuni S.V., Wani P.V., Patil A.S., 2012. Isolation of phosphate solubilizing fungi from rhizosphere of sugarcane \& sugar beet using TCP \& RP solubilization. Asian J. Biochem. Pharm. Res. 2(1): 237-244.
Markoglou A.N., Ziogas B.N., 2002. SBI-fungicides: fungicidal effectiveness and resistance in Botrytis cinerea. Phytopathol. Mediterr. 41: 120-130.

Matroudi S., Zamani M.R., Motallebi M., 2009. Antagonistic effects of three species of Trichoderma sp. on Sclerotinia sclerotiorum, the casual agent of canola stem rot. Egypt. J. Biol. 11: 37-44.

McLean K.L., Braithwaite M., Swaminathan J., Stewart A., 2012. Variability in control of onion white rot by Trichoderma atroviride under different disease pressures. Austr. Plant Pathol. 41: 341-346.

Mehrotra R.S., Aggarwal A., 2003. Plant Pathology. Tata McGraw-Hill Publishing Company Limited, New Delhi, India.

Meszka B., Bielenin A., 2009 . Bioproducts in control of strawberry Verticillium wilt. Phytopathol. 52: 21-27.

Mishra B.K., Mishra R.K., Mishra R.C., Tiwari A.K., YADAV R.S., Dikshit A., 2011. Biocontrol efficacy of Trichoderma viride isolates against fungal plant pathogens causing disease in Vigna radiata L. Appl. Sci. Res. 3: 361-369.

Morton D.T., Stroube N.H., 1955. Antagonistic and stimulatory effects of microorganism upon Sclerotioum rolfsii. Phytopathol. 45: 419-420.

Pikovskaya R.I., 1948. Mobilization of phosphorus in soil in connection with vital activity of some microbial species. Microbiol. 17: 362-370.

Shammugaiah V., Balasubramanian N., Gomathinayagam S., Manoharan P.T., Rajendran A., 2009. Effect of single application of Trichoderma viride and Pseudomonas fluorescens on growth promotion in cotton plants. Afr. J. Agric. Res. 4: 1220-1225.

Siameto E.N., Окотн S., Amugune N.O., Chege N.C., 2010. Antagonism of Trichoderma harzianum isolates on soil borne plant pathogenic fungi from Embu District, Kenya. J. Yeast Fungal Res. 1: 47-54.

Sookchaoy K., Panthachode S., Thipchu J., 2009. Screening of Trichoderma spp. for Phytophthora root and foot rot on Citrus sinensis biocontrol. Intl Conf. on the Role of Universities in Hands-On Education, 23-29 August, Thailand: 356-362 p.

Spiegel Y., Chet I., 1998. Evaluation of Trichoderma spp. as a biocontrol agent against soliborne fungi and plant-parasitic nematodes in Israel. Integ. Pest Manag. Rev. 3: 169-175.

Verma M., Brar S.K., Tyagi R.D., Surumpalli R.Y., VALÉRO J.R., 2007. Antagonistic fungi, Trichoderma spp.: Panoply of biological control. Biochem. Eng. J. 37: 1-20.

Watanabe T., 2010. Pictorial Atlas of Soil and Seed Fungi. Third Edition. CRC Press, USA.

White T.J., Bruns T.D., Lee S.B., TAylor J.W., 1990. Amplification and direct sequencing of fungal ribosomal RNA genes for phylogenetics. In: PCR Protocols: A Guide to Methods and Applications. M.A. Innis, D.H. Gelfand, J.J. Sninsky and T.J. White (eds), Academic Press, San Diego: 315-322 p. 
Williamson B., Tudzynski B., Tudzynski P., Van Kan J.A.L., 2007. Botrytis cinerea: the cause of grey mould disease. Mol. Plant Pathol. 8: 561-580.

Yadav J., Verma J.P., Tiwari K.N., 2011 . Solubilization of tricalcium phosphate by fungus Aspergillus niger at different carbon sources and salinity. Trends Appl. Sci. Res. 6(6): 606-613.

\section{IDENTYFIKACJA NOWYCH SZCZEPÓW TRICHODERMA O AKTYWNOŚCI ANTAGONISTYCZNEJ PRZECIWKO BOTRYTIS CINEREA}

Streszczenie: 52 izolaty grzybów z rodzaju Trichoderma zostały przebadane $\mathrm{z}$ użyciem techniki podwójnych kultur $\mathrm{w}$ celu oceny ich antagonistycznego oddziaływania przeciwko Botrytis cinerea. Wszystkie spośród badanych izolatów hamowały wzrost szarej pleśni. Wartość inhibicji wzrostu $B$. cinerea po 6 dniach inkubacji w temperaturze $25^{\circ} \mathrm{C}$ wynosiła $45-78 \%$. Największą aktywność antagonistyczną wykazały izolaty Tr43 i $\operatorname{Tr} 52(\operatorname{Tr} 43-76 \%, \operatorname{Tr} 52-78 \%)$. Izolaty te zostały zidentyfikowane jako Trichoderma atroviride. Na podstawie identyfikacji biochemicznej izolatów $\operatorname{Tr} 43$ i $\operatorname{Tr} 52$ z użyciem systemu do identyfikacji mikroorganizmów BIOLOG stwierdzono różnice w utylizacji 11, spośród 96 źródeł węgla. Dodatkowe testy biochemiczne wykazały zdolność izolatów $\operatorname{Tr} 43$ i Tr52 do syntezy sideroforów, kwasu indoilo3-octowego i chitynaz. Nie stwierdzono zdolności do rozpuszczania związków fosforu na podłożu wg Pikowskiej.

Received March 23, 2013; accepted August 1, 2013 